Article

\title{
New Climate Activism between Politics and Law: Analyzing the Strategy of the KlimaSeniorinnen Schweiz
}

\author{
Seline Keller ${ }^{1}$ and Basil Bornemann ${ }^{2, *}$ \\ ${ }^{1}$ Independent Researcher, Switzerland; E-Mail: seline.keller@gmx.ch \\ 2 Sustainability Research Group, Department of Social Sciences, University of Basel, 4051 Basel, Switzerland; \\ E-Mail: basil.bornemann@unibas.ch \\ * Corresponding author
}

Submitted: 4 November 2020 | Accepted: 15 February 2021 | Published: 28 April 2021

\begin{abstract}
Since 2016, a group of senior women organized in the association KlimaSeniorinnen Schweiz has been trying to legally force the Swiss government to take stronger climate protection measures. Parallel to the pursuit of a climate lawsuit, the KlimaSeniorinnen have developed into a growing social movement that is present in the media and participates in the public debate on climate change. Building on this specific climate litigation case, the present article analyzes the strategy formation of new actors in the field of climate governance. Based on existing concepts of social movement research, the strategy formation of the KlimaSeniorinnen is reconstructed in terms of a strategic actor who pursues certain strategic orientations in given strategic contexts. The empirical analysis of the strategic context (by means of opportunity structures), the strategic orientations (via collective action frames), and the strategic actor (by means of interviews) shows a double strategy. On the one hand, the KlimaSeniorinnen attempt to address a specific legal opportunity structure with an 'injustice frame,' which emphasizes human rights and the special vulnerability of older women to intense heat waves. On the other hand, they want to mobilize public support for an ambitious climate policy by additionally promoting a 'grandchildren frame,' which articulates altruistic values, such as responsibility towards future generations. Based on this analysis, both practical implications and consequences for future research on a new climate politics, which is increasingly taking shape between and across different arenas, are discussed.
\end{abstract}

\section{Keywords}

climate activism; climate litigation; climate movement; KlimaSeniorinnen Schweiz; new climate politics; strategy; Switzerland

\section{Issue}

This article is part of the issue "Is There a New Climate Politics? Emergency, Engagement and Justice" edited by Anna R. Davies (Trinity College Dublin, Ireland), Stephan Hügel (Trinity College Dublin, Ireland) and Vanesa Castán Broto (University of Sheffield, UK).

(C) 2021 by the authors; licensee Cogitatio (Lisbon, Portugal). This article is licensed under a Creative Commons Attribution 4.0 International License (CC BY).

\section{Introduction}

A growing number of societal actors are combating climate change on various fronts with different strategies (Dietz \& Garrelts, 2014; Dryzek, Norgaard, \& Schlosberg, 2013). In particular, the longstanding stalemate in international climate politics and the widely perceived failure of governments to take serious action, both of which were particularly evident during the spectacular fail- ure of the 15th Conference of the Parties (COP 15) to the United Nations Framework Convention on Climate Change in Copenhagen in 2009, have given rise to new actors and initiatives that seek to take matters into their own hands (Falkner, Stephan, \& Vogler, 2010). The increasingly differentiated field of climate governance includes activities as diverse as urban climate change experiments (Castán Broto \& Bulkeley, 2013), 'do-it-yourself' forms of action (Cloutier, Papin, \& Bizier, 
2018), sufficiency-oriented business models (Bocken \& Short, 2016), and the development of governance networks that seek to organize climate protection beyond politics and the state (Bäckstrand, Kuyper, Linnér, \& Lövbrand, 2017).

In recent years, however, in the wake of the Paris Agreement and its new approach to climate governance, which emphasizes the role of national governments in a mechanism of voluntary but binding goalsetting and reporting, we are witnessing both a new wave of political mobilization and a renewed invocation of government responsibility (de Moor, Vydt, Uba, \& Wahlström, 2020). The most prominent example is certainly the Fridays for Future movement, which started with local school strikes by young people and soon developed into a broad transnational climate movement far beyond the younger generation (Martiskainen et al., 2020). Messages proclaimed in mass public rallies and marches, such as "we strike until you act" or "follow the Paris Agreement," underscore that this new climate activism is again increasingly demanding political action from governments.

Besides these highly visible forms of urging governments to act, other groups of climate activists address their concerns through more formal strategies and via institutional channels. Rather than resorting to starting mass protests or provoking civil disobedience (Mattheis, 2020), for example, they are seeking to force governments to accept their responsibility for climate action through legal means. With Urgenda's lawsuit against the Dutch government certainly being the most prominent case, an increasing number of climate lawsuits have been filed by various actors against governments in different countries in recent years (Burger et al., 2017; Okubo, 2013; Peel \& Osofsky, 2017; Setzer \& Vanhala, 2019).

Meanwhile, research on climate litigation has continued to increase and-mainly from a legal perspectivehas produced comprehensive insights into the conditions and consequences of climate lawsuits in different contexts. However, social science analyses of the actors who engage in climate activism by legal means and their respective strategies are still scarce (Setzer \& Vanhala, 2019). In order to better understand the role of climate litigation in and for climate governance, there is still a need for more specific insights into the complex and diverse motivations of those who choose to mobilize the law in pursuing their strategies (Vanhala, 2013, p. 462). Accordingly, the aim of this article is to contribute to the understanding of the "community of capable and willing litigants" (Setzer \& Vanhala, 2019, p. 6) by analyzing the strategy of a specific litigant, namely the KlimaSeniorinnen Schweiz. Representing a group of elderly women, the KlimaSeniorinnen are the first to attempt to enforce stronger governmental climate protection measures through legal action in Switzerland. In addition to the legal process, the group has quickly developed into an actor that voices its demands in the broader public and thus receives ample media attention.
In addition to contributing a case study to climate litigation research, our analysis aims to shed light on how new actors in the field of climate politics are acting strategically in the context of increasingly differentiated climate governance. We argue that new actors in the climate movement, such as the KlimaSeniorinnen Schweiz, pursue multiple strategic orientations in more and more varied strategic contexts that provide social movements with different entry points to address their concerns.

In the following section, we briefly embed the case study of the KlimaSeniorinnen Schweiz in new climate politics (Section 2). Drawing on social movement theory and the analysis of political strategy, we specify three dimensions for understanding strategies of climate activism, namely strategic contexts, strategic orientations, and strategic actors (Section 3). We outline our methods, which combine a literature-based analysis of strategic contexts, a frame analysis of strategic orientations, and qualitative interviews to shed light on the activities of strategic actors (Section 4). Subsequently, we present the results of our three-dimensional strategy analysis of the KlimaSeniorinnen Schweiz (Section 5). We then reflect on the interplay between the strategy dimensions and discuss the broader implications of our analysis for new climate politics (Section 6). We conclude with perspectives for practice and future research.

\section{Background: New Climate Politics and the Climate Litigation of the KlimaSeniorinnen Schweiz}

\subsection{New Climate Politics and Climate Litigation}

Climate change has become a socio-political megatopic that permeates all areas of society (Dryzek et al., 2013). The increasingly diverse group of actors in climate activism reflects a multiplication of strategic entry points in ever more pluralized and institutionalized climate governance. For example, the progressive differentiation of climate governance-from international agreements to governmental climate protection programs-brings with it new opportunities to address and articulate climate political interests and concerns (Bäckstrand et al., 2017). In particular, the post-Paris regime represents a new reference and motivational basis for climate activism, as it is largely based on a principle of binding voluntariness that virtually calls for an active role of civil society actors in controlling governmental policies (Falkner, 2016; Kanie et al., 2019).

In addition to mobilizing political pressure on the streets through parties and parliaments, climate activism is increasingly resorting to institutional channels to articulate its concerns. Examples of this polity-directed activism are so-called climate lawsuits or litigation, with which social movements have been fighting for several years for more climate protection (Boutcher \& McCammon, 2019, p. 307; Hilson, 2002). To an increasing extent, they are being considered as potentially important mechanisms to support the implementation 
of nationally determined contributions under the Paris Agreement (Butterfield, 2018). Even if the obstacles in terms of both high costs and demanding criteria for standing are significant and the chances of success have so far been rather low, there are always new cases of climate complaints (Setzer \& Vanhala, 2019; Vanhala, 2012, 2013). In the further course of this article, we want to better understand the strategic considerations behind climate lawsuits by looking at the special case of the KlimaSeniorinnen Schweiz.

\subsection{The KlimaSeniorinnen Schweiz}

In 2014, Greenpeace International launched a strategy process with the aim of involving more people in the fight against climate change. After the first-instance victory of the Dutch organization Urgenda in 2015, Greenpeace Switzerland decided to initiate a similar climate litigation case in Switzerland. As the Federal Supreme Court is not able to review the compatibility of federal laws, such as the $\mathrm{CO}_{2}$ Act, with the Swiss Constitution, Greenpeace commissioned a legal opinion to examine another potential substantive legal foundation for a climate litigation case in Switzerland (see Bähr, Brunner, Casper, \& Lustig, 2018). The suggested procedural paththe request to issue a 'ruling on real acts' (Verfügung über Realakte) in terms of Article 25(a) of the Federal Act on Administrative Procedure-requires a particularly affected group of people as applicants. The lawyers identified women between 75 and 84 years of age as especially suitable. Their mortality rate is significantly higher during heat waves-also compared to men of the same age cohort. According to the legal opinion, senior women are particularly affected by climate change and also have an interest worthy of special protection, thus fulfilling two essential legal requirements for filing a lawsuit.

As no existing organization met the legal criteria for applicants, Greenpeace actively searched for a new group. Once a board of active women had been formed, they recruited more members by activating their networks. At the time of its official foundation in August 2016, the new association of the KlimaSeniorinnen Schweiz consisted of 273 members. Since then, this number has grown to over 1600 women (January 2020). The KlimaSeniorinnen are financed by private donations and by Greenpeace Switzerland. With increasing donations, the group has gained more and more financial independence and even reimbursed Greenpeace for some of its expenses.

\subsection{The Legal Process}

In November 2016, based on Article 25(a) of the Federal Administrative Procedure Act, the KlimaSeniorinnen filed their request for the discontinuation of failures in climate protection (Verein KlimaSeniorinnen Schweiz, 2016). They claimed that four administrative bodies, including the Swiss Federal Council; the Department of the
Environment, Transport, Energy, and Communications; and two of its subordinate agencies, failed to fulfil their obligations regarding the Swiss climate legislation and its implementation by 2020 and 2030 . They demanded that the government ends its illegal behavior and adjusts its omissions by initiating, among others, a preliminary legislative procedure to reinforce the greenhouse gas emission reduction targets and corresponding mitigation measures.

In substantive terms, the KlimaSeniorinnen base their claim on a variety of legal sources, beginning with the obligations arising from the Paris Agreement and through three provisions of the Swiss Constitution, namely the right to life (Art. 10, para. 1), the principle of sustainable development (Art. 73), and the precautionary principle (Art. 74, para. 2). Further, the claim is based on two articles of the European Convention on Human Rights, namely the right to life (Art. 2) and the right to respect private and family life (Art. 8).

In April 2017, the Department of the Environment, Transport, Energy, and Communications rejected the application, arguing that the KlimaSeniorinnen did not meet the formal requirements for legal standing. They denied the special affectedness of the KlimaSeniorinnen, asserting that they aimed at a global reduction of the $\mathrm{CO}_{2}$ concentration for everyone's benefit. The KlimaSeniorinnen lodged an appeal with the Federal Administrative Court, which was rejected in November 2017 based on the argument that the KlimaSeniorinnen had not demonstrated any specific affectedness that goes beyond the general concern. A further appeal with the Federal Court was also rejected in May 2020, prompting the group to file the case at the European Court of Human Rights in November 2020, where it is still pending.

\section{Framework: Analyzing Strategy Formation of Social Movement Actors}

Movement research has established three broad factors that explain the formation and activities of social movements: the institutional contexts movements face, which determine the opportunity spaces of their actions; the construction and interpretation of norms and ideas that guide their actions; and the organizational basis available to actors for mobilizing support and coordinating their actions (McAdam, 2017). For our empirical analysis of the strategy formation of the KlimaSeniorinnen Schweiz, we interpret these three bundles of factors as basic dimensions of strategy, with strategy referring to the deliberate attempt by actors to pursue certain, longerterm goals within a given context through coordinated action (Doherty \& Hayes, 2019; Raschke \& Tils, 2013). Strategy formation thus involves the development of a strategic goal orientation in relation to a specific strategic context by an organized strategic actor. We specify and operationalize these three elements-strategic context, strategic orientation, and strategic actor-as follows. 
Strategic context refers to both the structural and situational conditions within which and in relation to which groups decide whether or not to take action and how. By providing incentives for certain options and imposing constraints on others, the strategic context influences a movement's strategy-making. While it draws on the concept of political opportunity structures, which is widely used to explain the emergence and institutionalization of social movements in terms of the openness of political systems (Meyer \& Minkoff, 2004; Van Der Heijden, 1997), the concept of strategic context goes beyond that other concept in three ways: First, in addition to more or less open political structures, strategic contexts emphasize more contingent and dynamic factors, such as the receptivity of political elites to social movements' concerns (Hilson, 2002). Second, it reflects the pluralization of (climate) governance arenas and broadens the perspective to include "different openings" available to social movements to address their concerns (Vanhala, 2012, p. 526). In our case of climate litigation, we refer specifically to political and legal opportunities. While political opportunities open and close spaces for actors to influence the policy agenda, legal opportunities include all kinds of factors that condition access to legal governance (Vanhala, 2012, p. 526) and that influence the design of legal strategies (Fuchs, 2013). Specifically, legal opportunities refer to the "mechanics of the judicial process that shape access to the court, including what may be litigated, who can litigate and where and when such litigation can occur" (Vanhala, 2012, p. 527). Third, unlike opportunity structures, which imply a unidirectional imposition of opportunities and constraints on social movement actors, strategic contexts refer to a field of loosely connected and relatively autonomous arenas among which social movements can, to some degree, choose the most favorable (McAdam \& Tarrow, 2019).

Strategic orientations comprise the most important (cognitive) interpretation patterns and (normative) goals of movement actors, with which they try to reach a certain audience and/or influence the political process. We capture strategic orientations through an analysis of collective action frames. Frames refer to those "actionoriented sets of beliefs and meanings that inspire and legitimate the activities and campaigns of a social movement organization" (Benford \& Snow, 2000, p. 614). With the help of frames, movement actors attribute a specific (and always selective) meaning to social phenomena (Hänggli \& Kriesi, 2012): They problematize existing conditions (Entman, 1993), assign responsibilities for the problem and its solution, outline alternatives in terms of goals and options for action, and provide reasons why other actors should support the cause (Snow, 2004; Snow, Vliegenthart, \& Ketelaars, 2019).

Social movements generally refer to collectives of actors who engage in some form of joint action to pursue common goals (Snow, Soule, Kriesi, \& McCammon, 2019). The concept of strategic actors refers to the fact that social movement strategies are usually formulated and driven by a group of core actors who cannot control the social movement in a strict sense (Scharpf, 1997) but who have specific resources, such as finances, an organizational base, experience, knowledge, and networks, to significantly shape the movement's strategy (Edwards, McCarthy, \& Mataic, 2019). It is the strategic actors who take the lead in formulating and implementing strategic orientations within given strategic contexts (Ganz \& McKenna, 2019; Morris \& Staggenborg, 2004). To this end, they ensure the provision and maintenance of strategic capacity by building organizational structures and mobilizing resources and social support (Raschke \& Tils, 2013).

\section{Methodology: Combining Literature, Frame, and Interview Analysis}

Our case study on the KlimaSeniorinnen Schweiz combines three analytical steps, each of which relates to one of the conceptual elements of our strategy framework. To gain insights into the strategic context in which the KlimaSeniorinnen emerged and work, we first identified, based on existing literature, crucial elements of the political and legal opportunity structures in Switzerland that are likely to shape the strategy formation of the KlimaSeniorinnen.

To capture the strategic orientation, we conducted a frame analysis of the written communication of the KlimaSeniorinnen. The analysis included different kinds of publicly accessible documents, such as statutes, legal documents, and press releases (covering the period from July 2016 until the end of 2019), as well as a selection of media reports and parts of their website. These different groups of documents are aimed at different audiences, such as legal bodies (legal documents) or the media and the public (press releases, media reports). First, we conducted a deductive a priori categorization based on various studies of framing in environmental politics (Dahinden, 2002; Nisbet, 2009). Framing patterns, such as a focus on scientific facts or an emphasis on personal affectedness, served as a guideline for the subsequent inductive categorization. We mapped the patterns and figures of thought in the text material and combined them into a hierarchical order (Kuckartz, 2014). Following Benford and Snow (2000), we used the three frame functions-diagnostic, prognostic, and motivational-and added Entman's (1993) problem definition function to be able to more accurately depict the legal reasoning. These four functions served as superordinate categories, and all the codes were assigned to these functions. Thereby, we were able to distinguish two predominant category patterns, representing two collective action frames.

In a last analytical step, we conducted qualitative, semi-structured interviews with three key strategic actors: the co-president of the KlimaSeniorinnen Schweiz, the responsible project leader at Greenpeace Switzerland, and one of the association's lawyers. All 
interviews were conducted in January 2020. Conscious of fundamental limitations of reconstructing decisionmaking processes in movements (Blee, 2012), the aim of the interviews was, on the one hand, to obtain factual process knowledge about the organization and motivation of the strategic core actors and, on the other hand, to deepen and validate the results of the analysis of the strategic context and strategic orientations and link them to the interpretations of the actors (Bogner, Littig, \& Menz, 2014, pp. 18-19).

\section{Empirical Findings: Strategy Formation in the Case of the KlimaSeniorinnen Schweiz}

\subsection{Strategic Context}

The KlimaSeniorinnen face a comparatively open political opportunity structure in Switzerland (Kriesi, Koopmans, Duyvendak, \& Giugni, 1995). Besides the opportunities for social actors to participate in the regular legislative process through consultations, the direct democratic system in Switzerland offers numerous opportunities for social movements to bring their demands into the political arena (Kriesi \& Wisler, 1996; Van Der Heijden, 1997, p. 30). While a facultative referendum allows social movements to oppose parliamentary decisions, a federal popular initiative offers the opportunity to initiate changes and put problems on the political agenda. One could even say that the direct democratic system guides the actions of social movements into the conventional channels of political will and interest articulation as it delegitimizes unconventional, confrontational, or violent actions (Van Der Heijden, 1997, p. 43). The party-political composition of cantonal and national parliaments was rather non-receptive concerning climate issues when the KlimaSeniorinnen were founded. The party landscape was sharply divided with regard to environmental topics, with a majority of conservative and liberal positions. However, with the sharp increase in public attention being paid to the climate issue in recent years, which has translated into a strong increase in votes for green parties in cantonal elections and especially the 2019 elections for the National Parliament, the so-called green wave has provided favorable opportunities for addressing climate policy issues. Thus, these political factors have a signaling effect that reinforces the movement actors' perceptions of political opportunities for action (Meyer \& Minkoff, 2004).

In contrast, the legal opportunities appear less favorable. The non-existence of a constitutional court reduces the possibilities for social movements to pursue their demands through legal action. Therefore, no Swiss court is able to review the provisions of the $\mathrm{CO}_{2}$ Act for its compatibility with constitutional and human rights (Krumm, 2015 , p. 231). In addition, the legal process chosen by the KlimaSeniorinnen is characterized by complex procedural requirements, for example, with regard to the right to sue. This is demonstrated by the fact that the procedure was only disclosed through a detailed legal opinion from two lawyers. Grassroots movements without substantial financial and legal support are thus de facto excluded from legal action. Apart from the procedural issues, the legal dispute of the KlimaSeniorinnen is considered a pioneering project in Europe and the world (Bähr et al., 2018). Neither the Federal Court nor the European Court of Human Rights have ever ruled on such a legal case before. Although legal cases in other countries have served as a source of inspiration, no direct judgment could be used to build up the argumentation. This underlines that the legal process taken by the KlimaSeniorinnen is associated with considerable risks, which indicates rather unfavorable legal opportunities.

\subsection{Strategic Orientation}

Our analysis of the written communication of the KlimaSeniorinnen revealed two distinct strategic orientations associated with two clearly distinguishable but partially overlapping frames (see Table 1). An 'injustice frame' stresses the older women's particular affectedness in terms of health problems and a scientifically proven higher mortality rate during heat waves. In a magazine for elderly people, one of the board members stated: "We senior citizens are the population group most affected by the increasing heat waves, because our health problems and mortality are particularly high. This is why we are suing the government" (Hollenstein, 2019, translated by the authors). The problem of global warming is described as imminent and highly urgent. The injustice frame emphasizes the state's responsibility to protect human rights codified in the Swiss Constitution and international law. A member of the KlimaSeniorinnen said in an interview with an established daily newspaper:

The Federal Constitution states that [the government] must protect people from harmful impacts. The government has a duty to protect senior women. It must preventively protect us from negative effects on our health; this is the basis of our complaint. (Häne, 2016, translated by the authors)

The injustice frame underlines that the government's failure to protect senior women leads to a substantial violation of these women's rights and thus to a state of injustice. It predicts that more climate protection is needed to solve the problem, and hence the KlimaSeniorinnen have the right to resist by means of a climate litigation case. Potential activists are motivated by the portrayal of the KlimaSeniorinnen as a social movement with numerous members that counts on support from the public and from Greenpeace.

The 'grandchildren frame,' on the other hand, emphasizes the threat that global warming poses for future generations. For example, one of the climate seniors stated in an interview with a magazine for grandparents in Switzerland: "I want my grandchildren to 
Table 1. The frame category system.

\begin{tabular}{llll}
\hline Frame function & Injustice frame & Both frames (ambiguous categories) & Grandchildren frame \\
\hline $\begin{array}{lll}\text { 1. Problem definition } \\
\text { 2. Diagnosis }\end{array}$ & $\begin{array}{l}\text { Particular affectedness } \\
\text { Health problems } \\
\text { Scientific foundation }\end{array}$ & Urgency & Threat for future generations \\
& $\begin{array}{l}\text { Legal basis } \\
\text { Rights violation }\end{array}$ & Responsibility of state actors & \\
3. Prognosis & $\begin{array}{l}\text { Climate change litigation } \\
\text { The right to resist }\end{array}$ & More climate protection & \\
4. Motivation & & Support from Greenpeace and public & Protection of grandchildren \\
& & Social movement & Responsibility of the older \\
\end{tabular}

have a good life. A condition for this is that the climate stabilizes" (Gindely, 2016, translated by the authors). The grandchildren frame also blames state actors for not assuming their responsibility and demands more ambitious climate policies in order to solve the problem. The motivation function of the frame is twofold: On the one hand, it stresses the need to protect grandchildren. On the other, it accentuates that the older generations have contributed substantially to the climate crisis and therefore bear a certain responsibility to act.

The injustice frame is far more dominant than the grandchildren frame in all the types of analyzed communication. However, we observed significant differences: While the grandchildren frame was almost non-existent in legal documents, it was clearly visible in media reports, on the website, and in the association's leaflet (see Table 2). The latter are documents targeted at the mobilization of new members and supporters from the broader public. In addition, the injustice frame was largely self-contained, whereas the grandchildren frame rarely appeared by itself but rather in combination with the injustice frame.

\subsection{Strategic Actor}

The internal organization of the KlimaSeniorinnen reveals a clear division of tasks and roles. The team of lawyers mainly focuses on the legal representation of the litigation case. Greenpeace, on the other hand, is repeatedly described as the movement's secretariat. Even after the initiation and formation of the group, the NGO has continued to play a central strategic role: The project leader prepares most of the board meetings, designs parts of the written communication, and coordinates media relations. Greenpeace also conducted media training for those women most present in the media. According to statements by Greenpeace and senior women activists, Greenpeace's central organizational role was never concealed from the public, but it has not been proactively communicated either. The interviewees stress that the decision-making authority concerning the legal proceeding as well as the public appearances ultimately lie with the association's nine-member board and its general assembly. Likewise, it is the association and its members who decide what kind of information they want to communicate to the media and the public.

In terms of external relations, the three key strategic actors interviewed pointed at the importance of a global network on climate change litigation for the KlimaSeniorinnen case. Greenpeace and the board of the KlimaSeniorinnen maintain a close and steady dialogue with actors in new climate politics around the world. They also emphasize the advantages of exchanging legal arguments between cases in different contexts, even if courts are not bound by the judgments of courts in other countries. Thus, the case of the KlimaSeniorinnen was inspired by other climate litigation processes, and their legal argumentation based on the European Convention on Human Rights is intended to promote other court cases around the globe and especially in Europe.

Table 2. Distribution of frames.

\begin{tabular}{lccc}
\hline Example & Categories of injustice frame & Ambiguous categories & Categories of grandchildren frame \\
\hline Legal documents & $74 \%$ & $26 \%$ & $0 \%$ \\
Press releases & $58 \%$ & $36 \%$ & $6 \%$ \\
Website, leaflet, statutes & $39 \%$ & $49 \%$ & $12 \%$ \\
Media reports & $53 \%$ & $34 \%$ & $13 \%$ \\
\hline
\end{tabular}

Notes: Distribution of categories in the different types of analyzed communication. For example, $58 \%$ of all categories allocated in press releases are attributed to the injustice frame, $36 \%$ can be assigned to both frames, and $6 \%$ belong to the grandchildren frame. 
The KlimaSeniorinnen were far from inactive in the long interim periods between the filing of the legal complaints and the authorities' answers. They expressed their concerns through various side activities and active media work. Side activities included a delegation of the KlimaSeniorinnen traveling to the World Economic Forum in Davos or taking part in networking events at the COP 23 in Bonn in 2017. Several board members have regularly participated in podium events, conferences, or climate marches. For instance, the co-president contributed to a discussion board on health and the environment at the University of Lausanne in 2019. They have increasingly cooperated with other climate movements, such as young activists of the Fridays for Future movement, and have organized common events and performances. The association also supports a popular initiative aimed at anchoring the goals of the Paris Agreement in the Swiss Constitution ('Gletscherinitiative'). These activities were accompanied by a lot of active media work. The KlimaSeniorinnen published press releases regarding every step in the legal procedure and many of the side events. Moreover, several members were portrayed in well-known newspapers but also in issuespecific media, such as magazines for grandparents or women. As a result, the KlimaSeniorinnen achieved a comparatively broad media presence and were given the chance to emphasize their goals and demands and to explain the motivation behind their activism in front of different social groups and differentiated publics. The strategic actors interviewed emphasized how being associated with the KlimaSeniorinnen offers a lever for senior women to engage in climate politics. Moreover, their presence in the media is assessed positively not only for mobilization purposes but also because thus far the tendency has been for seniors not to have a strong voice in climate activism.

\section{Discussion: The Dual Strategy of the KlimaSeniorinnen and its Implications for New Climate Politics}

With regard to the relatively open political system in Switzerland, which basically offers many opportunities for social movements to put their claims on the political agenda, it seems counterintuitive that the KlimaSeniorinnen have chosen the protracted and costly legal route to force state actors to take more ambitious climate action. However, our strategy-oriented analysis sheds a more nuanced light on this seemingly counterintuitive choice, revealing more complex considerations of strategic actors pursuing strategic orientations in differentiated strategic contexts.

Interviews with key strategic actors suggest that the lawsuit initiated by the KlimaSeniorinnen is part of a dual strategy aimed at achieving simultaneous impacts in the legal and political arenas. Thus, the idea of founding the association originated from strategic considerations of Greenpeace Switzerland. The interview part- ners confirmed that the strategic purpose consisted not only of the legal case but also of the complementary political mobilization. The goal was to found a movement that could outlast the duration of the lawsuit. The choice of a legal route was particularly regarded as bearing the potential to attract greater political attention. In view of the polarization between left- and right-wing parties in the field of climate policy, it was aimed not so much at political decision-makers but rather at a broader public, especially the older generations, which had previously been less concerned about climate issues. In the wake of the green wave and a more receptive political atmosphere, the climate seniors increasingly reached out to the broader public and became engaged in political mobilization. With the green wave, their legal activities became more prominent and visible in the media, and they began to exploit their political potential. This legal-political double strategy manifests itself in the presence of two frames that indicate different strategic orientations and are tailored to different strategic contexts. With a frame that focuses on their own need for protection, the KlimaSeniorinnen try to address and create resonance in the legal system. The injustice frame focuses on the immediate consequences of climate change in the form of heat waves and emphasizes an acute threat to the health and physical integrity of older women, and thus their constitutional and human rights. This serves as the basis for claiming an illegal violation of the state's responsibility to protect this particularly vulnerable group of elder women. In contrast, the grandchildren frame refers to the consequences of unchecked climate change for the living conditions of future generations and emphasizes the responsibility of the older generation to take action. In its future-oriented and altruistic orientation, it aims at direct supporters, new members, and the general public. According to the interviewees, the altruistic motives in the grandchildren frame are particularly well suited for mobilizing the older generation, as they resonate with their intrinsic motivation for engagement.

Yet the political mobilization goals of the climate seniors are also supported by their legal strategy. Apart from the fact that the legal process itself receives considerable media attention, the choice of legal action does not only represent an appropriate form of activism (Hilson, 2002, p. 241) but also lends additional legitimacy to the concerns of the KlimaSeniorinnen and further strengthens their already high age-related integrity and credibility. Taken together, their social status, fragility, and rights-based legal activism give them a serious and legitimate voice in the climate movement and beyond. However, strategic actors are well aware that there is a tension between legal and political orientation. For example, the altruistic framing of the older generation as being responsible for future generations, aimed at mobilizing additional support from older people, could undermine their positioning as a particularly vulnerable group that deserves special protection by the state, as 
promoted in the injustice frame. Apart from the fact that the communication of the KlimaSeniorinnen is clearly dominated by the injustice frame, the strategic actors interviewed believe that the advantages of political mobilization outweigh the risks of weakening their position in the lawsuit.

Apart from adding another case study on legally oriented climate activism to existing research (Burger et al., 2017; Setzer \& Vanhala, 2019; Vanhala, 2013), our detailed empirical analysis of the KlimaSeniorinnen documents how climate litigation can be part of a broader strategy. The KlimaSeniorinnen did not follow a strict script but reacted flexibly to the development of their legal case and the reception of their proceeding in the media and the public. All the same, the active initiation of the group by Greenpeace, the targeted dual framing, the clear distribution of roles between the strategic actors, and the active media work are condensed into an overall picture of a strategic actor using a climate lawsuit not only for legal purposes but also for political mobilization. In particular, the case study shows how groups address "different openings" in targeted ways to articulate their concerns (Vanhala, 2012, p. 529) and how they develop different frames to do so.

Our case study once again underlines the role of strategic considerations in the formulation of legal claims (Wedeking, 2010). Thus, the legal (sub-)strategy of the KlimaSeniorinnen is based on a frame that highlights the actual dangers -in the form of heatwaves-of the ongoing climate change for the specific needs and rights of older women. The acute violation of the rights of this group is presented as a consequence of the government's failure to implement an ambitious climate policy, from which the necessity and duty of the state to pursue a more ambitious climate policy now is derived. In contrast to earlier climate lawsuits, two interlocking frame shifts are at work here: On the one hand, the time frame is shifting in such a way that climate change is no longer interpreted only as a risk for future generations, but rather as a currently manifest threat to a specific social group (Hilson, 2019). On the other, the reference to a present threat opens up the possibility of linking the consequences of climate change with human rights, thus reflecting the recent human rights shift in climate processes (Peel \& Osofsky, 2018). The emphasis on urgency, based on a shift from the future to the present, is also characteristic of other parts of the climate movement (de Moor et al., 2020).

As for the observed efforts concerning political mobilization, our case analysis confirms previous research, which has shown that legal strategies often have indirect political and social effects, and sometimes are even chosen because of them (Boutcher \& McCammon, 2019; Edelman, Leachman, \& McAdam, 2010; Vanhala, 2012). Yet, it points to a specific strategic quality of this political mobilization by law. Thus, the KlimaSeniorinnen were created purposefully and with professional support from Greenpeace as a group that is both enti- tled and promising with regard to filing legal action. At the same time, the legal strategy was only made possible by Greenpeace's financial means and institutional resources. While the collaboration between professional and financially strong movement actors and non-professional and non-institutionalized activists is not a novelty (Mol, 2000; Van Der Heijden, 1997), the case of the KlimaSeniorinnen is characterized by very targeted efforts to combine the strategic competence of professional actors with an intrinsically and authentically motivated civil activism. Apart from pointing out the tension between these divergent orientations of strategy and sincerity as it were (Holdo, 2019), the case is also an example of how this tension can be productively dealt with by means of differentiated yet connected communicative frames tailored to different contexts and audiences. Moreover, on the one hand, the case stands for the high degree of differentiation in climate activism. At the same time, it reveals the overlapping of and interaction between different strands of the climate movement, allowing for innovative liaisons between varying actors.

Finally, the KlimaSeniorinnen are an exemplary case of how climate activism is spreading to and increasingly permeating various areas of society. By purposefully linking climate change and its consequences with other issues, such as health, seniority, and femininity, new themes are created that engage new actors and create new publics (Nisbet, 2009). This is conveyed through increased media attention. For example, many media that have not previously dealt with climate issues have reported on the climate senior citizens. In this way, it was possible to reach parts of society that have so far been less intensively involved with the topic and to provide them with a voice in the climate discourse. In the progressive expansion and relating of more and more topics, social actors, and arenas also lies an integrative potential of climate activism.

\section{Conclusion}

Our case study on the strategy of the KlimaSeniorinnen Schweiz backs the general proposition that climate political activism is becoming increasingly differentiated and pluralized. Climate issues are motivating more and more (specific) social actors in different fields to engage with climate change. Our case study additionally points to a special strategic quality of recent climate activism. This is expressed in the targeted development of a social group that is eligible to file a lawsuit and in the close collaboration between professional and nonprofessional movement actors in pursuing, by means of communicative framing, a two-fold strategic orientation within given strategic contexts. On the one hand, the KlimaSeniorinnen try to address a specific legal opportunity structure with a human rights-based lawsuit by developing an injustice frame that emphasizes the special vulnerability of older women to intense heat waves 
and commits the state as a protector of its citizens and their constitutional and human rights to an ambitious climate policy. On the other hand, they want to mobilize public support for an ambitious climate policy in a specifically structured political arena. To this end, the KlimaSeniorinnen build on the senior women's social respect, on their credibility, and on the inherent legitimacy of their rights-based legal activism. Besides that, they count on a grandchildren frame, with which they seek to motivate and mobilize the older generation, in particular, by emphasizing altruistic values, such as responsibility towards future generations. On a more general level, the case of the KlimaSeniorinnen shows how legal climate activism seeks to find its way into and activate a certain climate governance mechanism that has developed since the Paris Agreement: a mechanism of voluntary national reduction obligations, whose functioning requires implementation pressure from different sides, including the broader public or the courts.

Future work on further legally oriented or other forms of climate activism should analyze the strategic quality of the new climate activism more broadly and more deeply. For example, the question arises whether multiple strategic orientations have become the norm and what changes in climate governance such 'strategization' of climate activism responds to. Further, the empirical effects and practical consequences of an increasingly strategically oriented climate activism should be examined. It would be interesting to find out how a strategically shaped movement develops when certain strategic contexts are closed down. What will happen to a strategically oriented actor like the KlimaSeniorinnen after the potential failure of their lawsuit? By generating a broader and more detailed picture about the strategies of diverse actors in an increasingly populated field of climate politics, research could also provide practical indications of the potentials of cooperative strategy development. For example, it could show how different groups of climate activists can combine their respective strategies to address, in a more coordinated manner, the various entry points of an increasingly differentiated climate governance architecture.

\section{Acknowledgments}

We thank two anonymous reviewers and the Academic Editors of this thematic issue for their constructive comments, which helped us improve the article. Basil Bornemann's contribution to this article was made as part of the project 'The Sustainabilization of the State,' supported by the Swiss National Science Foundation under Grant No. 178810.

\section{Conflict of Interests}

The authors declare no conflict of interests.

\section{References}

Bäckstrand, K., Kuyper, J. W., Linnér, B.-O., \& Lövbrand, E. (2017). Non-state actors in global climate governance: From Copenhagen to Paris and beyond. Environmental Politics, 26(4), 561-579. https://doi.org/ 10.1080/09644016.2017.1327485

Bähr, C. C., Brunner, U., Casper, K., \& Lustig, S. H. (2018). KlimaSeniorinnen: Lessons from the Swiss senior women's case for future climate litigation. Journal of Human Rights and the Environment, 9(2), 194-221. https://doi.org/10.4337/jhre.2018.02.04

Benford, R. D., \& Snow, D. A. (2000). Framing processes and social movements: An overview and assessment. Annual Review of Sociology, 26(1), 611-639.

Blee, K. M. (2012). Democracy in the making: How activist groups form. Oxford: Oxford University Press.

Bocken, N. M. P., \& Short, S. W. (2016). Towards a sufficiency-driven business model: Experiences and opportunities. Environmental Innovation and Societal Transitions, 18, 41-61. https://doi.org/10.1016/ j.eist.2015.07.010

Bogner, A., Littig, B., \& Menz, W. (2014). Interviews mit Experten: Eine praxisorientierte Einführung [Interviews with experts: A practice-oriented introduction]. Wiesbaden: Springer VS.

Boutcher, S. A., \& McCammon, H. J. (2019). Social movements and litigation. In D. A. Snow, S. A. Soule, H. Kriesi, \& H. J. McCammon (Eds.), The Wiley Blackwell companion to social movements (2nd ed., pp. 306-321). Hoboken, NJ: John Wiley \& Sons.

Burger, M., Gundlach, J., Kreilhuber, A., Ognibene, L., Kariuki, A., \& Gachie, A. (2017). The status of climate change litigation: A global review. Nairobi: United Nations Environment Programme.

Butterfield, B. (2018). The potential role of climate change litigation in furthering the mitigation objectives of the Paris Agreement. Asia Pacific Journal of Environmental Law, 21(1), 29-49. https://doi.org/ 10.4337/apjel.2018.01.02

Castán Broto, V., \& Bulkeley, H. (2013). A survey of urban climate change experiments in 100 cities. Global Environmental Change, 23(1), 92-102. https://doi.org/ 10.1016/j.gloenvcha.2012.07.005

Cloutier, G., Papin, M., \& Bizier, C. (2018). Do-ityourself (DIY) adaptation: Civic initiatives as drivers to address climate change at the urban scale. Cities, 74, 284-291. https://doi.org/10.1016/j.cities.2017. 12.018

Dahinden, U. (2002). Biotechnology in Switzerland: Frames in a heated debate. Science Communication, 24(2), 184-197.

de Moor, J., Vydt, M. D., Uba, K., \& Wahlström, M. (2020). New kids on the block: Taking stock of the recent cycle of climate activism. Social Movement Studies. Advance online publication. https://doi.org/ 10.1080/14742837.2020.1836617

Dietz, M., \& Garrelts, H. (Eds.). (2014). Routledge hand- 
book of the climate change movement. London and New York, NY: Routledge.

Doherty, B., \& Hayes, G. (2019). Tactics and strategic action. In D. A. Snow, S. A. Soule, H. Kriesi, \& H. J. McCammon (Eds.), The Wiley Blackwell companion to social movements (2nd ed., pp. 271-288). Hoboken, NJ: John Wiley \& Sons.

Dryzek, J. S., Norgaard, R. B., \& Schlosberg, D. (2013). Climate-challenged society (1st ed.). Oxford: Oxford University Press.

Edelman, L. B., Leachman, G., \& McAdam, D. (2010). On law, organizations, and social movements. Annual Review of Law and Social Science, 6(1), 653-685.

Edwards, B., McCarthy, J. D., \& Mataic, D. R. (2019). The resource context of social movements. In D. A. Snow, S. A. Soule, H. Kriesi, \& H. J. McCammon (Eds.), The Wiley Blackwell companion to social movements (2nd ed., pp. 79-97). Hoboken, NJ: John Wiley \& Sons.

Entman, R. M. (1993). Framing: Toward clarification of a fractured paradigm. Journal of Communication, 43(4), 51-58.

Falkner, R. (2016). The Paris Agreement and the new logic of international climate politics. International Affairs, 92(5), 1107-1125. https://doi.org/10.1111/ 1468-2346.12708

Falkner, R., Stephan, H., \& Vogler, J. (2010). International climate policy after Copenhagen: Towards a 'building blocks' approach. Global Policy, 1(3), 252-262. https://doi.org/10.1111/j.1758-5899.2010.00045.x

Fuchs, G. (2013). Strategic litigation for gender equality in the workplace and legal opportunity structures in four European countries. Canadian Journal of Law \& Society, 28(2), 189-208.

Ganz, M., \& McKenna, E. (2019). Bringing leadership back in. In D. A. Snow, S. A. Soule, \& H. Kriesi (Eds.), The Wiley Blackwell companion to social movements (2nd ed., pp. 185-202). Hoboken, NJ: John Wiley \& Sons.

Gindely, G. (2016, August). «Ich klage, damit meine Enkelinnen ein gutes Leben haben werden" ["I sue so that my granddaughters will have a good life"]. Grosseltern-Magazin, pp. 28-29. Retrieved from https://klimaseniorinnen.ch/wp-content/uploads/ 2016/05/029_wir-grosseltern-magazin_ Hintergrund_Klimaseniorinnen.pdf

Häne, S. (2016, September 3). «Sie unterschätzen uns offenbar" ["They obviously underestimate us"]. Tagesanzeiger. Retrieved from https://www. tagesanzeiger.ch/zuerich/stadt/der-bund-muss-unsschuetzen/story/22939835

Hänggli, R., \& Kriesi, H. (2012). Frame construction and frame promotion (strategic framing choices). American Behavioral Scientist, 56(3), 260-278. https://doi. org/10.1177/0002764211426325

Hilson, C. (2002). New social movements: The role of legal opportunity. Journal of European Public Policy, 9(2), 238-255.

Hilson, C. (2019). Framing time in climate change litigation. Oñati Socio-Legal Series, 9(3), 361-379. https:// doi.org/10.35295/osls.iisl/0000-0000-0000-1063

Holdo, M. (2019). Sincerity as strategy: Green movements and the problem of reconciling deliberative and instrumental action. Environmental Politics, 28(4), 595-614. https://doi.org/10.1080/09644016. 2018.1457294

Hollenstein, P. (2019, September). Klimaerhitzung: Warum wir klagen [Climate heating: Why we are suing]. Die Stimme der Senioren, pp. 8-9.

Kanie, N., Griggs, D., Young, O., Waddell, S., Shrivastava, P., Haas, P. M., . . . Körösi, C. (2019). Rules to goals: Emergence of new governance strategies for sustainable development. Sustainability Science, 14(6), 1745-1749. https://doi.org/10.1007/s11625019-00729-1

Kriesi, H., Koopmans, R., Duyvendak, J. W., \& Giugni, M. G. (Eds.). (1995). New social movements in Western Europe: A comparative analysis. Minneapolis, $\mathrm{MN}$ : University of Minnesota Press.

Kriesi, H., \& Wisler, D. (1996). Social movements and direct democracy in Switzerland. European Journal of Political Research, 30(1), 19-40.

Krumm, T. (2015). Föderale Staaten im Vergleich: Eine Einführung [Federal states in comparison: An introduction]. Wiesbaden: Springer VS.

Kuckartz, U. (2014). Qualitative text analysis: A guide to methods, practice \& using software. Los Angeles, CA: Sage.

Martiskainen, M., Axon, S., Sovacool, B. K., Sareen, S., Furszyfer Del Rio, D., \& Axon, K. (2020). Contextualizing climate justice activism: Knowledge, emotions, motivations, and actions among climate strikers in six cities. Global Environmental Change, 65. https:// doi.org/10.1016/j.gloenvcha.2020.102180

Mattheis, N. (2020). Unruly kids? Conceptualizing and defending youth disobedience. European Journal of Political Theory. Advance online publication. https:// doi.org/10.1177/1474885120918371

McAdam, D. (2017). Social movement theory and the prospects for climate change activism in the United States. Annual Review of Political Science, 20(1), 189-208. https://doi.org/10.1146/annurevpolisci-052615-025801

McAdam, D., \& Tarrow, S. (2019). The political context of social movements. In D. A. Snow, S. A. Soule, H. Kriesi, \& H. J. McCammon (Eds.), The Wiley Blackwell companion to social movements (2nd ed., pp. 19-42). Hoboken, NJ: John Wiley \& Sons.

Meyer, D. S., \& Minkoff, D. C. (2004). Conceptualizing political opportunity. Social Forces, 82(4), 1457-1492.

Mol, A. P. J. (2000). The environmental movement in an era of ecological modernisation. Geoforum, 31(1), 45-56. https://doi.org/10.1016/S0016-7185(99) 00043-3

Morris, A. D., \& Staggenborg, S. (2004). Leadership in social movements. In D. A. Snow, S. A. Soule, \& H. Kriesi (Eds.), The Blackwell companion to social move- 
ments. Malden, MA: Blackwell.

Nisbet, M. C. (2009). Communicating climate change: Why frames matter for public engagement. Environment: Science and Policy for Sustainable Development, 51(2), 12-23.

Okubo, N. (2013). Climate change litigation: A global tendency. In O. C. Ruppel, C. Roschmann, \& K. RuppelSchlichting (Eds.), Climate change litigation: International law and global governance (pp. 741-758). Baden-Baden: Nomos.

Peel, J., \& Osofsky, H. M. (2017). Climate change litigation: Lessons and pathways. Judicial Officers Bulletin, 29(11), 99-104.

Peel, J., \& Osofsky, H. M. (2018). A rights turn in climate change litigation? Transnational Environmental Law, 7(1), 37-67.

Raschke, J., \& Tils, R. (2013). Politische Strategie: Eine Grundlegung [Political strategy: A foundation] (2nd ed.). Wiesbaden: Springer VS.

Scharpf, F. W. (1997). Games real actors play: Actorcentered institutionalism in policy research. Boulder, CO: Westview Press.

Setzer, J., \& Vanhala, L. C. (2019). Climate change litigation: A review of research on courts and litigants in climate governance. Wiley Interdisciplinary Reviews: Climate Change, 10(3). https://doi.org/10.1002/wcc. 580

Snow, D. A. (2004). Framing processes, ideology, and discursive fields. In D. A. Snow, S. A. Soule, \& H. Kriesi (Eds.), The Blackwell companion to social movements (pp. 380-412). Malden, MA: Blackwell.

Snow, D. A., Soule, S. A., Kriesi, H., \& McCammon, H. J. (2019). Introduction: Mapping and opening up the terrain. In D. A. Snow, S. A. Soule, H. Kriesi, \& H. J.
McCammon (Eds.), The Wiley Blackwell companion to social movements (2nd ed., pp. 1-16). Hoboken, $\mathrm{NJ}$ : John Wiley \& Sons.

Snow, D. A., Vliegenthart, R., \& Ketelaars, P. (2019). The framing perspective on social movements: Its conceptual roots and architecture. In D. A. Snow, S. A. Soule, H. Kriesi, \& H. J. McCammon (Eds.), The Wiley Blackwell companion to social movements (2nd ed., pp. 392-410). Hoboken, NJ: John Wiley \& Sons.

Van Der Heijden, H. (1997). Political opportunity structure and the institutionalisation of the environmental movement. Environmental Politics, 6(4), 25-50.

Vanhala, L. (2012). Legal opportunity structures and the paradox of legal mobilization by the environmental movement in the UK. Law \& Society Review, 46(3), 523-556.

Vanhala, L. (2013). The comparative politics of courts and climate change. Environmental Politics, 22(3), 447-474.

Verein KlimaSeniorinnen Schweiz. (2016). Begehren um Einstellung von Unterlassungen im Klimaschutz im Sinne von Art. 25a VwVG sowie Art. 6 Ziff. 1 und 13 EMRK [Request for discontinuation of omissions in climate protection in terms of Article 25a, Administrative Procedure Act, and Article 6 paras. 1 and 13, European Convention on Human Rights]. Zurich: ettlersuter. Retrieved from https://klimaseniorinnen. ch/wp-content/uploads/2016/11/161124-Gesuchum-Erlass-anfechtbarer-Verfuegung_final.pdf

Wedeking, J. (2010). Supreme court litigants and strategic framing. American Journal of Political Science, 54(3), 617-631. https://doi.org/10.1111/j.15405907.2010.00450.x

\section{About the Authors}

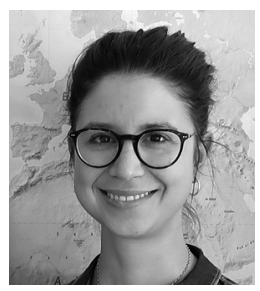

Seline Keller holds an MA degree in European Global Studies from the University of Basel. In her studies, she focused on the intersections between human rights, social developments and politics, including in the fields of migration and climate activism. As part of the research for her MA thesis she first dealt with the KlimaSeniorinnen and their litigation case. At present, she works as a Professional Associate in the field of migration.

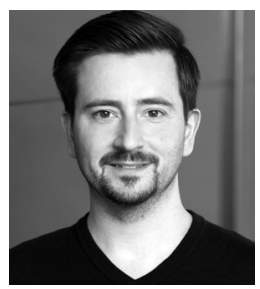

Basil Bornemann is a Postdoctoral Researcher and Lecturer at the Sustainability Research Group, University of Basel. He has an interdisciplinary study background in environmental sciences and holds a PhD in political science. His research focusses on sustainability-oriented governance transformations and their democratic implications in various areas such as energy and food. At present, he is involved in a research project on the sustainabilisation of the state funded by the Swiss National Science Foundation (SNSF). 